\title{
The Effects of TV Newscast Use in Teaching Writing for the Vocational School Students
}

\author{
Irfan Effendi ${ }^{1}$ \\ ${ }^{3}$ Muria Kudus University \\ ${ }^{1}$ irfan.eve@gmail.com \\ Ahdi Riyono $^{2}$ \\ ${ }^{2}$ Muria Kudus University \\ 2ahdi.riyono@gmail.com
}

\begin{abstract}
Writing ability is a skill that must be mastered by students. One of the media can be applied in teaching writing is TV Newscast. The objective of this research is to find out whether the writing ability of the eleventh-grade students of SMKN 1 Kudus in 2016/2017 academic year after being taught by using TV newscast is better than before. This study is experimental research; in this research, the writer used one group pre-test post-test design. There are two variables; they are TV newscast (independent variable) and the students' writing ability (dependent variable). The population of the research is the eleventh-grade students of SMKN 1 Kudus in 2016/2017 academic year. The writer used random cluster sampling as the technique to take the sample. Then XI AK 1 (accountancy class) consists of 38 students was taken. The research used achievement test as instrument for measuring the students' writing ability before and after being taught by using TV newscast and then the data were analyzed using the statistical formula. Based on the result of this research, the $t_{0}$ (obtained) was higher than $t$-critical (20.09>1.56). It showed that $\mathrm{t}_{0}$ (obtained) on the critical area and the null hypothesis $\left(\mathrm{H}_{0}\right)$ is rejected. Then the conclusion is that the writing ability of the eleventh-grade students of State Vocational School 1 Kudus in 2016/2017 academic year after being taught by using TV newscast is significant.
\end{abstract}

\section{ARTICLE HISTORY}

Received 22 April 2017

Accepted 10 September 2017

\section{KEYWORDS}

the effects of TV newscast; teaching writing; the vocational school students

\section{Introduction}

Writing ability is an ability to express and organize the ideas, opinions, and feelings in the written form that requires content, organization, grammar, vocabulary, and mechanical aspect. Writing ability must be mastered by students especially in senior high school level. William (1989) states that writing is a creative act that requires interpreting or making sense of an experience, a text, an event. Based on the curriculum 2013 and syllabus of English subject, writing report text is one of the subjects for the eleventh-grade students in SMKN 1 Kudus. Usually, the teacher gave explanation to students about the report text then gave a topic and asks them to make it into writing form. Sometimes, the teacher also divided students into several groups 
and asked them to discuss some topics in their group. At the end of meeting, the teacher corrected their writing. Although the teacher used some strategies or techniques, some students still have some problems in writing report text, especially in vocabulary mastery, finding and composing the idea into writing form. Some of the students could not pass the standard score that is 75 . The researchers observed this problem when did teaching practice in SMK N 1 Kudus.

To solve this problem, the researchers tried to employ TV newscast as a media in teaching writing report text. It is used as an exercise for students through writing the content of a video TV newscast in English with English subtitles. In the class, the writer showed the video of TV newscast to students, and they have to construct the information on TV newscast into report text. The students have to write a report text around 8-10 sentences. The video of TV newscast can be obtained or downloaded from the internet such as YouTube or news website. Terrell (1986) proved that combining unknown words with visual aids could facilitate and enhance vocabulary learning. Bahrani (2011) in his thesis under the title "The Role of Audiovisual Mass Media News in Language Learning" proved that greater exposure to mass media news improves students' ability in language learning. Based on some statements above, the writer decided the title of this research is "The Effects of TV Newscast use in Teaching Writing for The Vocational School Students." The researchers hoped that the writing ability of the eleventh-grade students of SMKN 1 Kudus in 2016/2017 academic year after being taught by using TV newscast would be better than before.

Based on the background of the research, the writer decided the statements of the problem are:

1. How is the writing ability of the eleventh-grade students of SMKN 1 Kudus in 2016/2017 academic year before being taught by using TV newscast better than before?

2. How is the writing ability of the eleventh-grade students of SMKN 1 Kudus in 2016/2017 academic year after being taught by using TV newscast better than before?

3. Is there a significant difference between the writing ability of the eleventh-grade students of SMKN 1 Kudus in 2016/2017 academic year before and after being taught by using TV newscast?

\section{Literature Review}

\section{Writing Report Text}

William (1989:18) states that writing is a creative act that requires interpreting or making sense of something: an experience, a text, an event. Writing ability is more complex, it is an ability to express and organize the ideas, opinions, and feelings in 
the written form that requires content, organization, grammar, vocabulary, and mechanical aspect.

Report text report is a text that explains and elaborates some factual information related particular objects, matters, or thing based on observation and scientific. The purpose is to present information about something in general and describes an entire class of things, whether natural or made. For examples: human, animals, plants, rocks, natural and social phenomena.

The generic structure of report text consists of a title, a general classification, and description. Then the language features of report text are introducing a group or general aspect, using conditionals and logical connectives, using the simple present tense, relating verb, action verb, using scientific language.

\section{Teacher And Students-Centered Learning}

\section{Teacher-Centered Learning}

Huba and Freed (2000) described teacher-centered learning as students passively receive information, the emphasis is on the acquisition of knowledge, and the teacher's role is to be primary information giver and primary and evaluator. The teacher talks, while the students exclusively listen. During activities, students work alone, and collaboration is discouraged. The students do not have to worry that students will miss an important topic because the teacher directs all classroom activities. Some models of learning used in teacher-centered learning are lecturing, explaining and demonstrating, question and answer, seatwork, homework, etc.

\section{Student-Centered Learning}

Student-centered learning is a perspective which focuses on the learners' experiences, perspectives, backgrounds, talents, capacities, and needs. It creates a learning environment conducive to learning and promotes the highest levels of motivation, learning, and achievement for all learners (McCombs \& Whisler, 1997). Students learn important communicative and collaborative skills through group work. They learn to direct their learning, ask questions and complete tasks independently. So the students are more interested in learning activities when they can interact with one another and participate actively. Some models of learning used in student-centered learning are jigsaw, STAD, small group discussion, discovery learning, collaborative learning, etc.

\section{Types Of Learning Style}

Learning styles are the ways of person to accumulate and assimilate information. It has been well research that each has a preferred style of learning, and understanding of it can influence students learning positively (Hartman, 1995). 
People may have more than one kind of learning style as a combination of different learning styles. When students recognized their learning styles, the can apply good learning styles according to their learning styles so that students can maximize academic and non-academic achievement. There are three basic kinds of learning styles, they are:

\section{Auditory}

An auditory learner prefers listening to what is being presented. They have an excellent response to voices, for example, in a lecture or group discussion. Auditory learners tend to benefit most from traditional teaching techniques. Many teachers use a lecture-style forum, presenting information by talking to their students. Regulating voice tone, inflection, and body language will help all students maintain interest and attention. Auditory learners succeed when directions are read aloud, speeches are required, or information is presented and requested verbally.

\section{Visual}

A visual learner absorbs and retains information better when it is presented in, for example, pictures, diagrams, and charts. They like to learn through written language, such as reading and writing tasks. They remember what has been written down, even if they do not read it more than once. They like to write down directions and pay attention to lectures if they watch them.

\section{Kinesthetic}

A kinesthetic learner prefers a physical experience. They have a good response in touching or feeling an object or learning property. Kinesthetic learners are most successful when engaged with the learning activity. They acquire information fastest when participating in a science lab, drama presentation, field trip, dance, or other active activity.

\section{Media Of Teaching}

Media is an instrument which is used to attract the students' attention and motivation in learning. According to Van Els et al. (1984), media are all aids which may be used by teachers and learners to attain certain educational objectives. Furthermore, media can be specified in different ways. The teacher needs the media to make the students more active and interested in learning process. The use of media in the teaching and learning process is very important because the students will be easier to catch the material of learning by using media. There are four kinds of media, they are: 


\section{Visual}

Visual media are devices which are presented in order to provide the learner with an accurate visual and true picture. For examples: a letter, a picture of storybook, photos, painting, diagrams, charts, etc.

\section{Audio}

Audio media are devices that produce sounds. The sounds contain educational messages. Education audio may be spoken words or simple sounds of something, sounds of an animal, calling sounds, noises, etc. Examples of audio media: radio, record, and cassettes, etc.

\section{Audio Visual}

Audiovisual media is a combination of visual and audio media. Both sounds and pictures must occur in audio-visual media, for example, TV newscast, video, film, etc.

\section{Tactile}

Tactile is media which has three dimensions and sense of touch. Tactile is used in teaching and learning process because of the limitation of the real things which can not be presented in the class, for example, puppet, doll, mannequin, globe, action figure, etc.

\section{Tv Newscast}

TV newscast is a video of news that is shown on TV. The video of TV newscast can be found or downloaded from the internet such as YouTube or news website. It is used as an exercise for students through writing the content of a video TV newscast in English with English subtitles. In the class, the teacher showed the video of TV newscast to students, and they had to construct the information on TV newscast into report text. The students had to write a report text around 8-10 sentences. Oxford and Crookall (1990) found that the combination of audio and visual aids provided learners with multiple opportunities to access more parts of the brain and to process information more effectively. The audiovisual media such as TV newscast helped people in finding and composing the idea to be more creative. Some steps were done by the teacher as follows:

1. Showing the video of TV newscast to students.

2. Dividing the students into groups. One group consists of four students.

3. Giving questions related to TV newscast. The students have to take a note related to the questions. 
4. Showing the video of TV newscast again.

5. Asking the students to use their notes to make a report text.

\section{Method Of The Research}

\section{Design of the Research}

This study is experimental research. In this research, the writer used one group pre-test post-test design. The writer gave pre-test to take the first data. Then the treatments applied were only in one group. After that, the researchers gave post-test to know the students' ability to write report text after being taught by using TV newscast. The pattern of the designed above was described as follow:

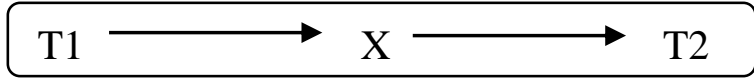

Pre-test Treatment Post-test

Figure 3.1: Single-group pretest - posttest design

This research has two variables. They are:

1. Independent Variable $(\mathrm{X})$ was the presumption cause of the dependent variable. In this research, the independent variable is TV newscast.

2. Dependent Variable ( $\mathrm{Y}$ ) was the presumption effect of the independent variable. It is the students' writing ability.

\section{Population and Sample}

The population of this research was the whole eleventh grade students of SMKN 1 Kudus in 2016/2017 academic year. There were 14 classes (XI AK 1, 2, 3, XI PS, XI AP 1, 2, 3, XI PM 1, 2, XI JB 1, 2, 3, XI TB 1, 2) that consist of 546 students. They had the same material based on the syllabus, and English subject is taught $2 \times 3$ lesson hours (one lesson hour is 40 minutes) in a week in the eleventh grade. So the population of this research assumed as homogenous.

The researchers used a cluster random sampling technique to take the sample. According to Gay and Airasian, random cluster sampling is sampling technique randomly selects groups, not individuals. One class was taken randomly by using lottery from 14 classes. Then XI AK 1 (accountancy class) consists of 38 students was taken as a sample.

\section{The instrument of the Research}

The researchers used an achievement test as instrument to collect the data, by giving written test; pre-test and post-test to measure the students' writing ability. The students made report text individually. There were some criteria to analyze the students' writing tests. They were as follows: 
Table 1. Analytical Scoring Rubric by Weigle (2002)

\begin{tabular}{|c|c|c|}
\hline Components & Score & Indicators \\
\hline \multirow[t]{4}{*}{ Content } & 4 & Relevant to the topic and easy to understand \\
\hline & 3 & Rather relevant to the topic and easy to understand \\
\hline & 2 & relevant to the topic but is not quite easy to understand \\
\hline & 1 & Quite relevant but it is not easy to understand \\
\hline \multirow[t]{4}{*}{ Organization } & 4 & Most of the sentences are related to the main idea \\
\hline & 3 & Some sentences are related to the main idea \\
\hline & 2 & Few sentences are related to the main idea \\
\hline & 1 & The sentences are not related to each other \\
\hline \multirow{4}{*}{$\begin{array}{l}\text { Vocabulary } \\
\text { and } \\
\text { Mechanic }\end{array}$} & 4 & $\begin{array}{l}\text { A few errors in choice of words, spelling, and } \\
\text { punctuation }\end{array}$ \\
\hline & 3 & $\begin{array}{l}\text { Some errors in choice of words, spelling, and } \\
\text { punctuation }\end{array}$ \\
\hline & 2 & $\begin{array}{l}\text { Occasional errors in choice of words, spelling, and } \\
\text { punctuation }\end{array}$ \\
\hline & 1 & $\begin{array}{l}\text { Frequent errors in choice of words, spelling, and } \\
\text { punctuation }\end{array}$ \\
\hline \multirow[t]{4}{*}{ Grammar } & 4 & A few grammatical inaccurate \\
\hline & 3 & Some grammatical inaccurate \\
\hline & 2 & Numerous grammatical inaccurate \\
\hline & 1 & Frequent grammatical inaccurate \\
\hline
\end{tabular}

\section{Data Collecting}

The writer uses observation and achievement test by giving a written test to collect the data. There were two kinds of tests used; pre-test and post-test.

1. Pre-test

A pre-test is conducted before the implementation of TV newscast to find out the score of writing report text of the class which observed. The students were given a theme of the story which is familiar with them. Students should write with minimum 8-10 sentences.

2. Observation

Observation is used to observe the students' writing ability in learning process while the writer applied the treatment by using TV newscast.

3. Post-test

Post-test is used to find out if TV newscast is effective to teach writing report text. The post-test was conducted after the implementation of TV newscast to measure the students' writing ability after being taught by using TV newscast. The test used was same as the test used in the pre-test which consists of minimum 8-10 sentences to be written by the students. 


\section{Analysis}

Analyzing data is the process of analyzing the acquired data from the result of the research. In this research, the technique of data analysis used is statistical analysis with a t-test. A t-test was used between pre-test and post-test. There were some models for organizing all hypotheses testing as follows: counting the mean, counting the standard deviation, testing the t-test.

The conclusion of the statistic will be examined as follows: Ho: $\mu 1>\mu 2$.

\section{Finding And Discussion}

The students were given pre-test before being taught by using the TV. There were 38 students in the eleventh accountancy 1 class of SMKN 1 Kudus. The result of pre-test shows that the students' highest score is 75 and the lowest score is 35 . The mean of pre-test was 46.94, and the standard deviation is 9.66. It categorized as a low score.

After that, the writer gave treatment to students four times after got the data from pre-test. It is then continued by giving post-test to the students to know whether the treatment is effective or not. The result of post-test shows that the students' highest score is 90 and the lowest score is 50 . The mean of the post-test is 82.47 , and the standard deviation is 2.52 . It categorized as an excellent score.

Table 2. Students Score of Pre-test and Post-test

\begin{tabular}{llll}
\hline No & Name & Pre-test score & Post-test score \\
\hline 1 & A N P & 55 & 80 \\
\hline 2 & B Y S & 40 & 80 \\
\hline 3 & D A S & 65 & 90 \\
\hline 4 & D F & 50 & 85 \\
\hline 5 & D C & 50 & 80 \\
\hline 6 & E S & 35 & 60 \\
\hline 7 & E N & 55 & 85 \\
\hline 8 & E M & 75 & 90 \\
\hline 9 & E D Y & 40 & 80 \\
\hline 10 & F A & 35 & 70 \\
\hline 11 & G E W & 50 & 85 \\
\hline 12 & L F Z & 65 & 80 \\
\hline 13 & L F & 65 & 90 \\
\hline 14 & M M & 40 & 75 \\
\hline 15 & M U & 45 & 85 \\
\hline 16 & M N A & 55 & 80 \\
\hline
\end{tabular}




\begin{tabular}{llll}
\hline 17 & M R A & 45 & 85 \\
\hline 18 & M G M & 40 & 50 \\
\hline 19 & M N R & 35 & 65 \\
\hline 20 & N E & 40 & 85 \\
\hline 21 & N A S R & 40 & 55 \\
\hline 22 & N Y & 40 & 80 \\
\hline 23 & N H & 50 & 85 \\
\hline 24 & N & 40 & 85 \\
\hline 25 & N W H & 40 & 85 \\
\hline 26 & N F L & 50 & 80 \\
\hline 27 & P R & 45 & 85 \\
\hline 28 & P J & 65 & 85 \\
\hline 29 & P M S & 45 & 85 \\
\hline 30 & R M & 40 & 85 \\
\hline 31 & R U I & 40 & 85 \\
\hline 32 & S A & 45 & 85 \\
\hline 33 & S M & 45 & 85 \\
\hline 34 & S W & 70 & 90 \\
\hline 35 & T D S & 40 & 85 \\
\hline 36 & U H & 40 & 85 \\
\hline 37 & V W S & 40 & 85 \\
\hline 38 & W A K & 60 & 85 \\
\hline & SUM & $\mathbf{1 8 1 5}$ & $\mathbf{3 0 7 5}$ \\
\hline & & & \\
\hline
\end{tabular}

The summary of the calculation between the students' writing ability before and after being taught by using TV newscast as follow:

Table 3. Students' writing ability before and after using TV newscast

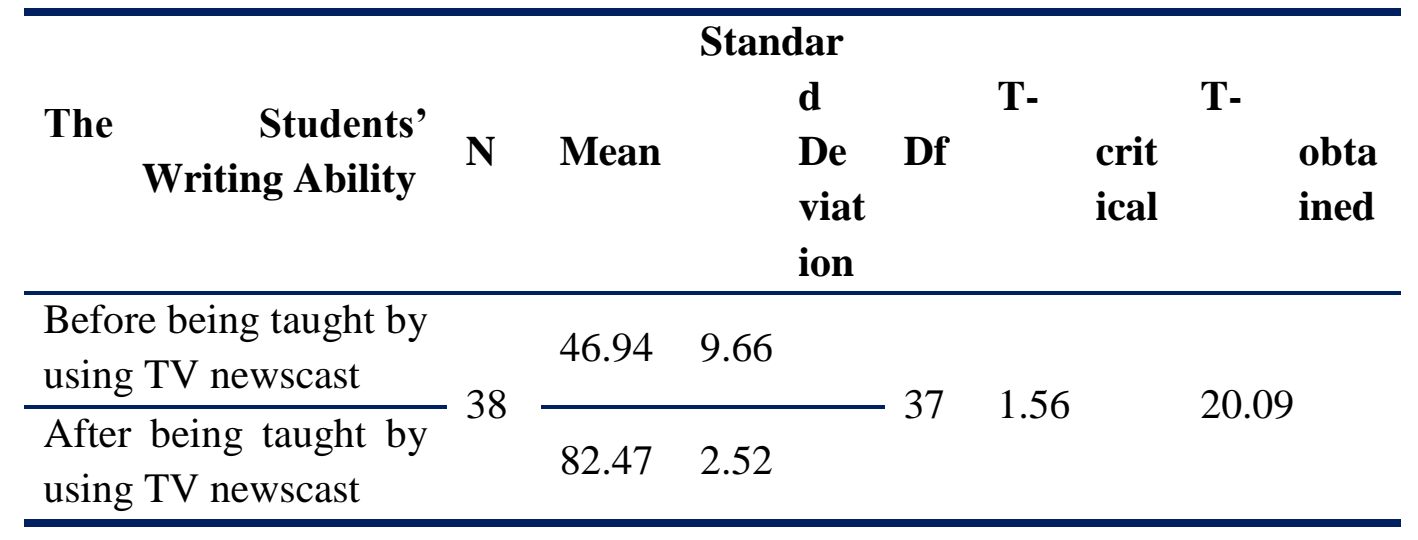


The sampling distribution that shows the t-obtained versus t-critical can be seen as follow:

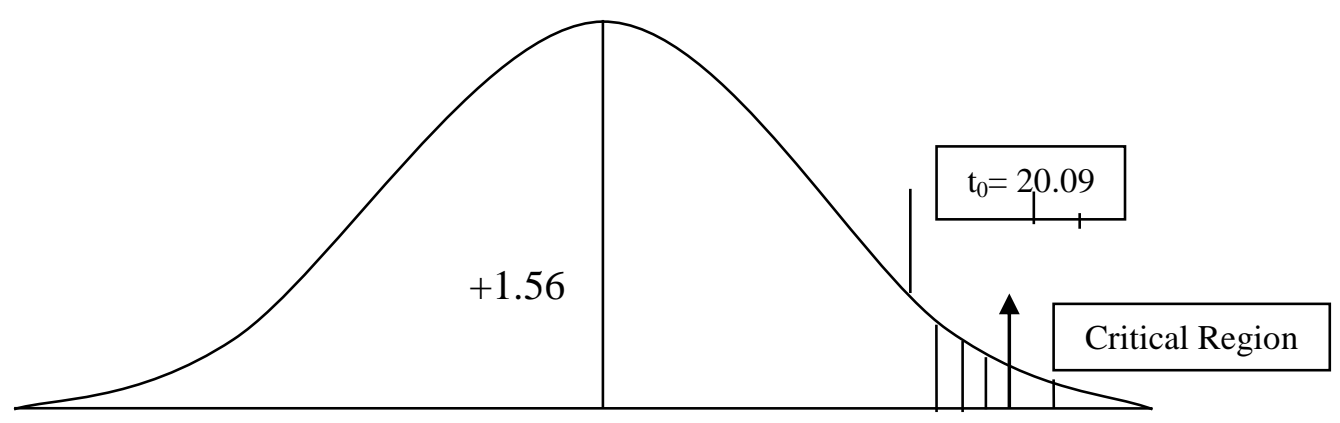

From figure 4.1 above, the $\mathrm{t}_{0}$ (obtained) is higher than $\mathrm{t}$-critical $(20.09>1.56)$. It means that $t_{0}$ (obtained) falls in the critical region and the null hypothesis $\left(\mathrm{H}_{0}\right)$ is rejected. It can be concluded that the writing ability of the eleventh-grade students of SMKN 1 Kudus in 2016/2017 academic year after being taught by using TV newscast is better than before.

Teaching English in SMKN 1 Kudus is based on curriculum 2013 which uses the model of students-center learning. In learning styles of the teaching-learning process, the eleventh grade AK 1 as a sample of research preferred a combination of different learning styles; they are auditory and visual style. The writer uses TV Newscast as a media in teaching writing report text. TV newscast is media which has combination style between auditory and visual. In applying this media, the writer uses small group discussion technique to teach the students.

The result showed that the writing ability of the eleventh-grade students of SMKN 1 Kudus in 2016/2017 academic year after being taught by using TV newscast was better than before. It caused TV newscast as a media of teaching writing report text is suitable with the type of students' learning style. It was proved by the mean score of pre-test is 46.94 , while the mean score of post-test is 82.47 and the $t_{0}$ (obtained) is higher than t-critical $(20.09>1.56)$.

In teaching writing report text, usually, the English teacher explained to students about the report text then gave a topic and asks them to make it into writing form. Sometimes, the teacher also divided students into several groups and asked them to discuss some topics in their group. At the end of meeting, the teacher corrected their writing. Although the teacher used some strategies, techniques, and media, some students still have some problems in writing report text. To solve this problem, the writer used TV newscast as a media in writing report text. It is used as an exercise for students through writing the content of a video TV newscast in English with English subtitles. In the class, the writer showed the video of TV newscast to students, and they have to construct the information on TV newscast into report text. TV newscast has some advantages such as could facilitate and enhance 
vocabulary learning, enable students to practice writing without any pressure, finding and composing the idea to be more creative.

The research was conducted for six meetings consisting of two meetings for pre-test and post-test and four meetings for treatment. The writer gave pre-test without using any media at first to measure the students writing ability before being taught by using TV newscast. Then the writer gave treatment to students by using TV newscast four times. The procedures in teaching were the same in every meeting but used different video of TV Newscast in every treatment. The first treatment, the students were given exercise to write a report text by using TV newscast of "Tsunami," then the second treatment was "Cheetah," the third treatment was "Herbs and Spices," and the fourth treatment was "Death Valley."

The researchers explained all steps to use TV newscast in learning writing report text. The writer showed the video of TV newscast to students and divided them into several groups. One group consists of four students. Then gave questions related to TV newscast as a clue or guide for students in writing the content of the video. The students have to take a note related to the questions. After that, the writer showed the video of TV newscast again and asked the students to use their notes to make a report text. After that, the researchers gave post-test to measure the students writing ability after being taught by using TV newscast. The students' mean score between pre-test and post-test shows that $(46.94<82.47)$. It means their writing ability after being taught by using TV newscast is better than before. The post-test result could get a high mean score because the students were given exercise to write a report text by using TV newscast in every treatment.

Based on explanation above, it can be concluded that teaching writing by using TV newscast is effective to teach writing, especially report text. It is in line with the study by Bahrani (2011) in his thesis under the title "The Role of Audiovisual Mass Media News in Language Learning." He found that mass media news could help students in studying English and overcome the students' problem in language learning. This study had the same field with TV newscast, so it is believed that TV newscast as a medium of teaching is effective in teaching writing report text.

\section{Conclusion}

The result of the research showed that the writing ability of the eleventh-grade students of SMKN 1 Kudus in 2016/2017 academic year after being taught by using TV newscast was better than before proved by the mean score of pre-test is 46.94 , while the mean score of post-test is 82.47 . Moreover, the $t_{0}$ (obtained) is higher than $\mathrm{t}$-critical (20.09>1.56). It means that $\mathrm{t}_{0}$ (obtained) falls in the critical region and the null hypothesis $\left(\mathrm{H}_{0}\right)$ is rejected. The researchers concluded that TV newscast as was effective to teach writing, especially report text. 


\section{References}

Arikunto, Suharsimi, Prosedur Penelitian: Suatu Pendekatan Praktik, $13^{\text {th }}$ Ed., Jakarta, PT. Rineka Cipta, (2006).

Bahrani, Taher, in "The Role of Audiovisual Mass Media News in Language Learning" Thesis of Islamic Azad University, Iran: Language and Linguistics Faculty, (2011).

Cakir, Ismail, "The Use of Video as an Audio-Visual Material in Foreign Language Teaching Classroom," Thesis of Kirikkale Universitas, Turki: Eigitim Fakulty, (2006).

Depdiknas, Curriculum of Education, Indonesia: National Education Department, (2006).

Gay, L, and Airasian, P, Educational Research: Competencies for Analysis and Application, $7^{\text {th }}$ Ed., Upper Saddle River, NJ: Pearson Education, (2003).

Hartman, V. F. () Teaching and learning style preferences: Transitions through technology. VCCA Journal 9, no. 2. (1995). Summer: 18-21. http://www.so.ccva.us/veca/hart1.htm

Healey, Joseph F, Statistics: A Tool for Social Research, $9^{\text {th }}$ Ed., Virginia: Wadsworth Publisher, (2000).

Huba, M.E., \& Freed, J.E. Teacher-centered vs. learner-centered paradigms. (2000).

Mc Combs, B. L. \& Whistler, J. S. The Learner-Centered Classroom and School. Strategies for Increasing Student Motivation and Achievement. San Francisco: Jossey Bass Publishers. (1997)

Newsweb, "Report Text", www.newsinlevels.com, retrieved on January 5, (2017), $08.00 \mathrm{pm}$.

Oxford and Crookall, The Audio Visual Media for Learning, England: Pearcon Education, (1990).

Terrell, H, Teaching by Principles An Interactive Approach to Language Pedagogy, 2nd Ed., New York: Pearson Education Company, (2001). 
Van Els, Theo et al. Applied Linguistics and the Learning and Teaching of Foreign Languages. New York: Chapman and Hall, Inc. (1984).

Wang, Chia, "Learning L2 Vocabulary with American TV Drama from the Learner's Perspective" Thesis of National Taiwan Normal University, Taiwan: English Department, (2011).

William, The Way in Teaching Writing, Virginia: TESOL Inc, (1989). 